\title{
PENGARUH JARAK ANTAR ELEKTRODA PLAT BESI TERHADAP PRODUKTIVITAS DAN EFISIENSI GENERATOR HHO MENGGUNAKAN METODE ELEKTROLISIS AIR LAUT DENGAN KATALIS KOH
}

\author{
Akhmad Daudi Shabahaini'1), Mastiadi Tamjidillah²) \\ 1,2Program Studi Teknik Mesin \\ Fakultas Teknik Universitas Lambung Mangkurat \\ Jl. Ahmad Yani Km. 36 Banjarbaru, Kalimantan Selatan, 70714 \\ Telp. 0511-4773858 \\ email: daudy.shabahaini@gmail.com
}

\begin{abstract}
HHO gas is an alternative energy that can replace fossil energy sources. HHO gas itself can be produced in several ways, one of which uses water electrolysis. Water is given a direct electric charge so that the water molecule $\left(\mathrm{H}_{2} \mathrm{O}\right)$ splits into $\mathrm{HHO}$ gas. This study aims to determine the effect of iron plate electrode distance on the productivity and efficiency of $\mathrm{HHO}$ generator by varying it from $2 \mathrm{~mm}, 4 \mathrm{~mm}$ and $6 \mathrm{~mm}$, for the water used is the sea water of Teluk Tamiang Village which was dissolved together with $\mathrm{KOH}$ of 3,04\%. From the experiments carried out the data obtained in the form of voltage, current, time to produce $50 \mathrm{ml}$ of $\mathrm{HHO}$ gas, $\mathrm{pH}$ of sea water, $\mathrm{pH}$ of the solution before and after electrolysis, and temperature after electrolysis. The data is then processed so that it gets the highest productivity at a distance of $2 \mathrm{~mm}$ with an average flow rate of $0,89 \mathrm{ml} / \mathrm{s}$ and the highest efficiency at a distance of $2 \mathrm{~mm}$ with an average of $23,83 \%$. This is because at a distance of $2 \mathrm{~mm}$ the electrons move from the cathode electrode to the anode electrode faster and the resulting resistance is smaller, so that the HHO generator produces faster oxyhydrogen bubbles and less power and energy consumption.
\end{abstract}

Keywords: HHO gas, Productivity, Efficiency

\section{PENDAHULUAN}

Meningkatnya kebutuhan energi di dunia dewasa ini menjadi pertimbangan bagi dunia tidak terkecuali di Indonesia, cadangan minyak bumi dipertimbangkan sekitar 16,6 miliar barel, sedangkan untuk batubara sekitar 32,26 miliar ton (Nugraha, 2016).

Dari mulai menipisnya cadangan energi fosil tersebut maka perlu adanya pengembangan energi alternatif (renewable energy) sebagai sumber energi terbarukan. Adapun energi yang dapat dijadikan energi terbarukan antara lain gas hidrogen. Gas hidrogen sendiri merupakan salah satu energi yang ramah lingkungan sehingga menjadi perhatian besar banyak negara, terutama di negara maju (Yanuar \& Djoko, 2013).

Hidrogen sendiri bukanlah sumber energi (energy source) melainkan pembawa energi (energy carrier), berarti hidrogen tidak bisa didapatkan bebas di alam ataupun dieksploitasi seperti sumber energi fosil, yang berarti hidrogen harus di produksi. Salah satu cara untuk memproduksi hidrogen adalah dengan proses elektrolisis air atau pemecahan air (Isana, 2010).

Hidrogen merupakan unsur kimia pada tabel periodik yang memiliki simbol $\mathrm{H}$ dan nomor atom 1. Memiliki berat 1,0079 amu, sehingga menjadikannya gas paling ringan diantara gas lainnya. Pada suhu dan tekanan standar hidrogen tidak bewarna, tidak berbau, bersifat non-logam, bervalensi tinggi, dan merupakan gas diatomik yang mudah terbakar. Entalpi pembakaran hidrogen adalah -286 kJ/mol (Wahyudin, 2012). 
Hidrogen terbakar menurut persamaan kimia:

$2 \mathrm{H}_{2}(g)+\mathrm{O}_{2}(g) \rightarrow 2 \mathrm{H}_{2} \mathrm{O}(\mathrm{l})+572 \mathrm{~kJ}(286 \mathrm{~kJ} / \mathrm{mol})$

Hidrogen sendiri memiliki massa jenis $0,0838 \mathrm{~kg} / \mathrm{m}^{3}$, LHV (Low Heating Value) 119,93 MJ/kg, dan Flame velocity $265-325 \mathrm{~cm} / \mathrm{s}$ (Gohar and Raza, 2017).

Gas hasil pemecahan air $\left(\mathrm{H}_{2} \mathrm{O}\right)$ dengan proses elektrolisis. Gas yang didapatkan dari proses elektrolisis air tersebut adalah gas hidrogen $\left(\mathrm{H}_{2}\right)$ dan Oksigen $\left(\mathrm{O}_{2}\right)$, dengan komposisi 2 Hidrogen dan 1 Oksigen atau $\mathrm{HHO}$ (Lowrie, 2005). Untuk memecah senyawa air dan menjadikannya $\mathrm{H}_{2}$ dan $\mathrm{O}_{2}$ murni memanfaatkan arus listrik searah atau arus DC (Direct Current), molekul-molekul air dipecah menjadi unsur-unsur asalnya, gas yang dihasilkan tadi menjadi gas $\mathrm{HHO}$ atau oxyhydrogen atau Brown's Gas.

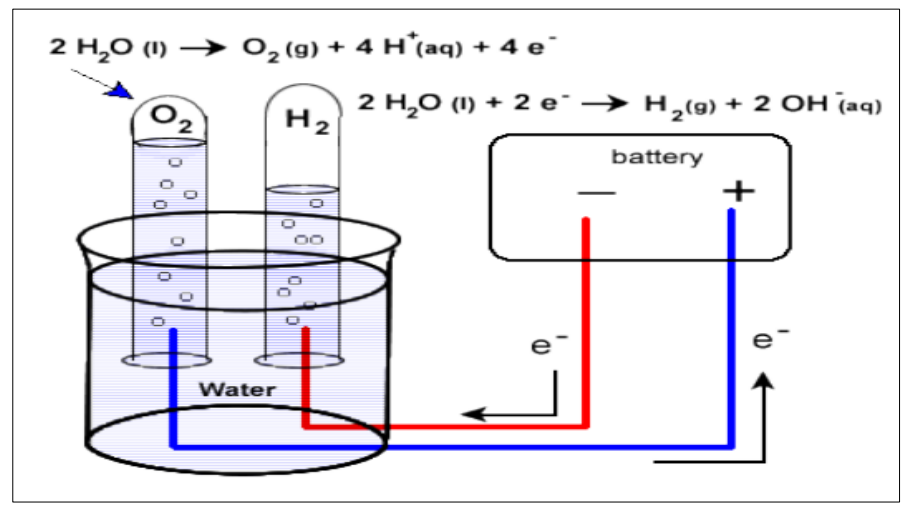

Gambar 1. Proses Elektrolisis Air

Beda potensial yang dihasilkan oleh arus listrik antara anoda dan katoda akan mengionisasi molekul air menjadi ion positif dan ion negatif. Pada katoda terdapat ion positif yang menyerap elektron dan menghasilkan molekul ion $\mathrm{H}_{2}$, dan ion negatif akan bergerak menuju anoda untuk melepaskan elektron dan menghasilkan molekul ion $\mathrm{O}_{2}$. Reaksi total elektrolisis air adalah penguraian air menjadi hidrogen dan oksigen. Gas hidrogen dan oksigen yang dihasilkan dari reaksi ini membentuk gelembung-gelembung pada elektroda dan dapat dikumpulkan.

Air laut adalah air dari laut atau samudra, air laur memiliki kadar garam rata-rata 3,5\%. Artinya dalam 1 liter $(1000 \mathrm{ml})$ air laut mengandung $35 \mathrm{gram}$ garam. Meskipun kebanyak air laur di dunia memiliki kada garam sekitar 3,5\%, air laut ada juga berbeda-beda kandungan garamnnya. Yang paling tawar adalah di Timur Teluk Finlandia dan di Utara Teluk Bothnia, keduanya bagian dari Laut Baltik. Air laur paling asin terdapat di Laut Merah, suhu tinggi dan sirkulasi terbatas membuat penguapan tinggi dan sedikit masukkan air dari sungai-sungai. Garam-garaman yang terdapat di air laut meliputi 55\% Klorida (Cl), 31\% Natrium $(\mathrm{Na}), 8 \%$ Sulfat $\left(\mathrm{SO}_{4}\right), 4 \%$ Magnesium $(\mathrm{Mg}), 1 \%$ Kalsium $(\mathrm{Ca}), 1 \%$ Kalium $(\mathrm{K})$, dan $<1 \%$ Bikarbonat, Bromida, Asam Borak, Strotium dan Florida.

$\mathrm{KOH}$ (Kalium Hidroksida) atau yang juga dikenal dengan nama caustic potash merupakan senyawa anorganik basa kuat yang juga termasuk dalam golongan heavy chemical industry. Heavy chemical merupakan bahan kimia yang diproduksi dalam partai besar dan harga murah dengan industri lain sebagai konsumen utamanya. $\mathrm{KOH}$ dapat digunakan sebagai bahan untuk menpercepat laju reaksi pada proses elektrolisis atau katalis. $\mathrm{KOH}$ dengan konsentrasi tinggi akan membuat larutan semakin mendekati 0 (nol) ketahanannya, tetapi akan menyebabkan proses elektrolisis semakin panas dan mempercepat korosi pada elektroda. 
Prosentase katalis yang besar dapat menaikkan laju aliran gas $\mathrm{HHO}$, dikarenakan bertambahnya prosentase katalis akan menyebabkan elektrolit semakin banyak mengandung kation dan anion. Semakin banyaknya kation dan anion pada larutan elektrolit menyebabkan elektrolit dapat menghantarkan arus yang besar sehingga energi listrik yang digunakan akan semakin banyak untuk melakukan proses elektrolisis (Marayanti, 2008). Menaikkan prosentase katalis akan membuat larutan akan semakin basa.

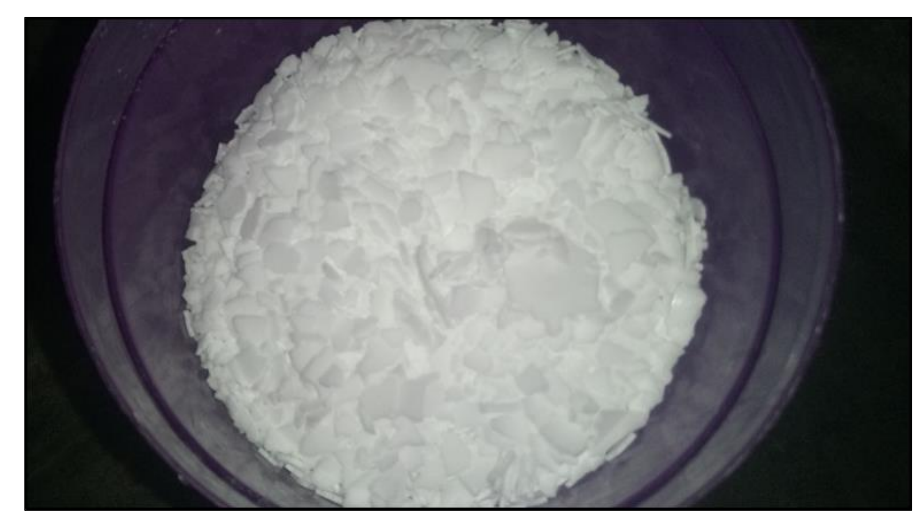

Gambar 2. Kalium Hidroksida (KOH)

Untuk mengukur derajat keasaman atau kebasaan suatu zat cair maka digunakan alat ukur $\mathrm{pH}$. Alat ukur $\mathrm{pH}$ ada bermacam-macam, ada yang disebut dengan kertas lakmus dan ada juga $\mathrm{pH}$ meter berbentuk pen, pada penelitian ini menggunakan pH meter berbentuk pen dengan merek ATC dengan akurasi 0,2.

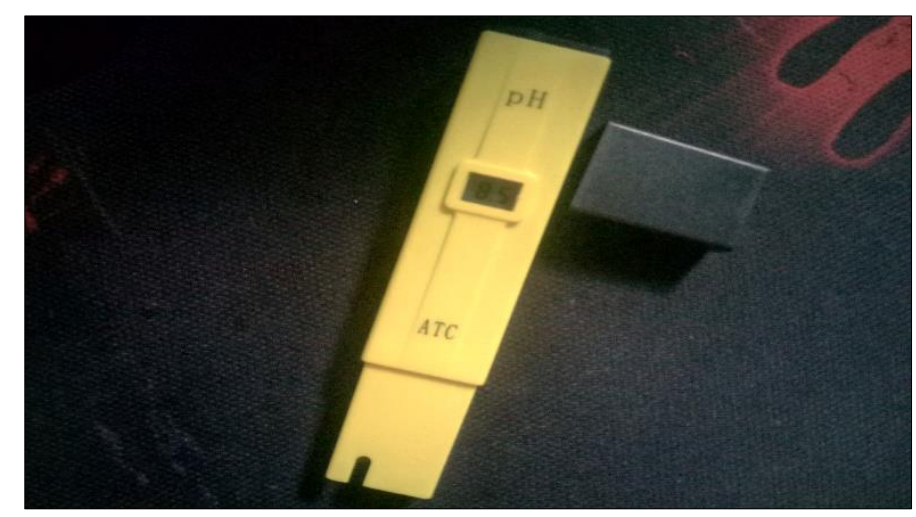

Gambar 3. pH meter

Sel elektrolisis berbeda dengan sel volta jika sel volta reaksi oksidasinya berlangsung spontan dan energi kimia yang menyertai reaksi kimia diubah menjadi energi listrik. Maka pada sel elektrolisis terjadi reaksi kebalikan dari sel volta yang potensial selnya negatif, atau pada keadaan normal tidak akan terjadi reaksi dan reaksi dapat terjadi bila diinduksi dengan energi listrik dari luar.

Rangkaian sel elektrolisis menyerupaik sel volta, yang membedakan sel elektrolisis dari sel volta yaitu pada sel elektrolisis komponen voltmeter diganti dengan sumber arus. Larutan yang ingin dielektrolisis ditempatkan pada camber, kemudian elektroda dicelupkan kedalam larutan. 


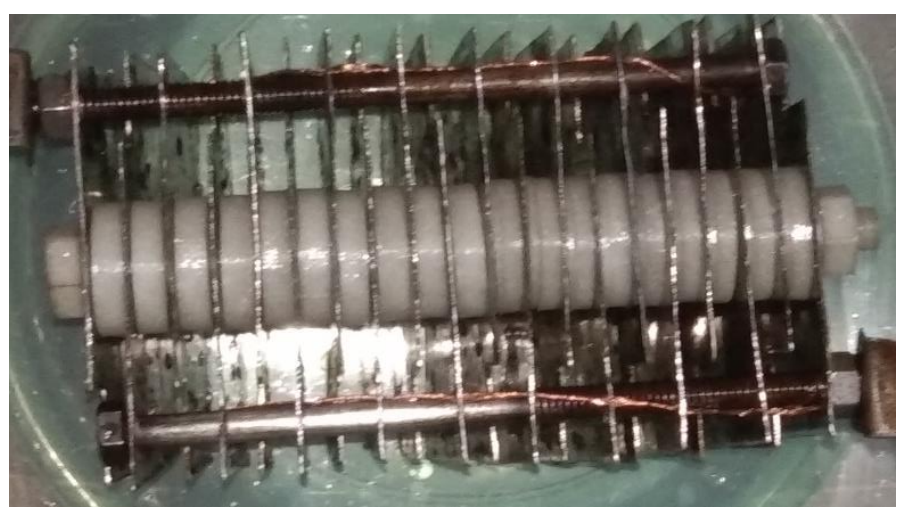

Gambar 4. Sel Elektrolisis

Elektroda berperan sebagai tempat terjadi reaksi. Reaksi reduksi terjadi di katoda, sedangkan reaksi oksidasi terjadi di anoda. Kutub negatif sumber arus ke katoda (karena memerlukan elektron) dan kutub positif sumber arus mengarah ke anoda. Akibatnya, katoda bermuatan negatif dan menarik kation-kation yang akan tereduksi menjadi endapan logam. Sebaliknya pada anoda, anoda akan bermuatan positif dan menarik anion-anion yang akan teroksidasi menjadi gas.

Reaksi yang terjadi adalah sebagai berikut:

Di Katoda $: 2 \mathrm{H}_{2} \mathrm{O}(\mathrm{I})+2 \mathrm{e}^{-} \rightarrow \mathrm{H}_{2}(g)+2 \mathrm{OH}^{-}(\mathrm{aq})$

Di Anoda $: 2 \mathrm{OH}^{-}(\mathrm{aq}) \rightarrow 1 / 2 \mathrm{O}_{2}(g)+\mathrm{H}_{2} \mathrm{O}(\mathrm{l})+2 \mathrm{e}^{-}$

Total $\quad: \mathrm{H}_{2} \mathrm{O}(\mathrm{I}) \rightarrow \mathrm{H}_{2}(\mathrm{~g})+1 / 2 \mathrm{O}_{2}(\mathrm{~g})$

Produktivitas dan efisiensi dari generator $\mathrm{HHO}$ dipengaruhi oleh beberapa parameter sebagai berikut:

1. Laju aliran gas $\mathrm{HHO}$.

Laju aliran gas dapat diketahui dari persamaan sebagai berikut ini:

$\mathrm{Q}=\frac{\text { Volume }}{\mathrm{t}}$

Dimana:

$\mathrm{Q} \quad=$ Laju aliran gas $\mathrm{HHO}(\mathrm{ml} / \mathrm{s})$

Volume = Volume gas $\mathrm{HHO}(\mathrm{ml})$

$\mathrm{T} \quad=$ Waktu diperlukan (s)

2. Daya listrik

Daya listrik dapat diketahui dari persamaan sebagai berikut ini:

$P=V \times I$

Dimana:

$\mathrm{P} \quad=$ Daya yang digunakan generator $\mathrm{HHO}$ (watt)

$\mathrm{V} \quad=$ Beda potensial (Volt)

$\mathrm{I}=$ Kuat Arus (Ampere)

3. Energi listrik

Energi listrik dapat diketahui dari persamaan sebagai berikut ini:

$E=P \times t$

Dimana:

$\mathrm{E} \quad=$ Energi listrik (Joule)

$\mathrm{P}=$ = Daya yang digunakan generator $\mathrm{HHO}$ (watt)

$\mathrm{t} \quad=$ Waktu diperlukan $(\mathrm{s})$ 
4. Efisiensi generator $\mathrm{HHO}$

Efisiensi generator $\mathrm{HHO}$ dapat diketahui dari persamaan berikut ini:

$$
\begin{array}{ll}
\eta & =\frac{\text { Volume } \times \rho \times \mathrm{LHV}}{\mathrm{P}} \times 100 \% \\
\eta & =\text { Efisiensi generator } \mathrm{HHO}(\%) \\
\text { Volume } & =\text { Volume gas } \mathrm{HHO}(\mathrm{ml}) \\
\rho & =\text { Massa jenis gas } \mathrm{HHO}(\text { gram/liter }) \\
\mathrm{LHV} & =\text { Low Heating Value }(\text { nilai pembakaran terendah) }(\mathrm{MJ} / \mathrm{Kg}) \\
\mathrm{P} & =\text { Daya yang digunakan generator } \mathrm{HHO} \text { (watt) }
\end{array}
$$

Tujuan dari penelitian ini yang diingin dicapai adalah untuk mengetahui hubungan antar jarak elektroda plat besi dari proses elekrolisis air laut dengan penambahan $3,04 \% \mathrm{KOH}$ sebagai katalis terhadap produktivitas dan efisiensi dari generator $\mathrm{HHO}$.

\section{METODE PENELITIAN}

Pengujian dilakukan secara eksperimental dengan cara ini akan di uji pengaruh dari variasi jarak elektroda terhadap produktivitas dan efisiensi generator $\mathrm{HHO}$ untuk menghasilkan gas $\mathrm{HHO}$ (Brown's Gas). Penelitian ini menggunakan variasi jarak elektroda $2 \mathrm{~mm}, 4 \mathrm{~mm}$ dan $6 \mathrm{~mm}$.

Variabel terkontrol adalah jenis dan dimensi elektroda besi $90 \mathrm{~mm} \times 110$ $\mathrm{mm} \times 1 \mathrm{~mm}$, volume air $2300 \mathrm{ml}$, massa katalis $70 \mathrm{gram}$. Variabel yang diamati adalah $\mathrm{pH}$ air laut sesudah dan sebelum dielektrolisis, waktu yang diperlukan untuk menghasilkan $50 \mathrm{ml}$ gas $\mathrm{HHO}$, tegangan (volt), arus (ampere), dan temperatur.

\section{Alat dan Bahan Penelitian}

Alat dan bahan penelitian yang digunakan dalam penelitian ini yaitu: generato $\mathrm{HHO}$, water trap, alat ukur volume gas, DC adaptor \& battery charger, volt ampere meter digital, $\mathrm{pH}$ meter, termometer, multimeter, timbangan digital, stopwatch, gelar ukur. Sedangkan untuk bahan yang digunakan adalah air laur Teluk Tamiang, Kecamatan Pulau Laut Tanjung Selayar, Kabupaten Kotabaru, Kalimantan Selatan, $\mathrm{KOH}$ (Kalium Hidroksida).

Khusus untuk generator $\mathrm{HHO}$, water trap dan alat ukur volume gas tidak didapatkan dari pasar atau komersial, tetapi alat-alat tersebut dibuat sendiri dengan menggunakan teori-teori yang ada.

Generator HHO (Gambar 5.) sendiri mempunyai beberapa bagian-bagian di dalamnya, yaitu: Sel elektrolisis yang tersusun dari plat-plat besi dan diberi washer kemudian dikencangkan menggunakan baut isolator, ditambahkan baut konduktor sebagai penghantar listrik ke plat anoda dan katoda.

Water trap (Gambar 6.) terbuat dari toples yang kemudian diberi dop ban tubeless sebagai niple sebagai jalur untuk gas $\mathrm{HHO}$ di dalam selang dan diberi air hingga menenggelamkan selang pada bagian dalam.

Alat ukur volume gas (Gambar 7.) terdiri dari dua buah botol bekas, satu botol kecil yang kemudian di ukur per $50 \mathrm{ml}$ menggunakan gelas ukur yang diberi air kemudian diberi tanda, dan dimasukkan ke dalam botol besar sehingga mulut dari botol kecil bertemu dengan selang jalur masuk gas $\mathrm{HHO}$. 


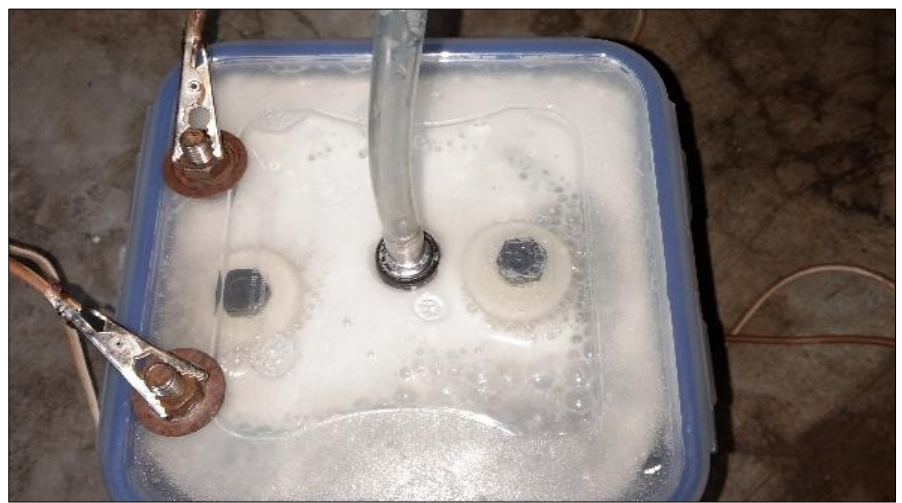

Gambar 5. Generator HHO

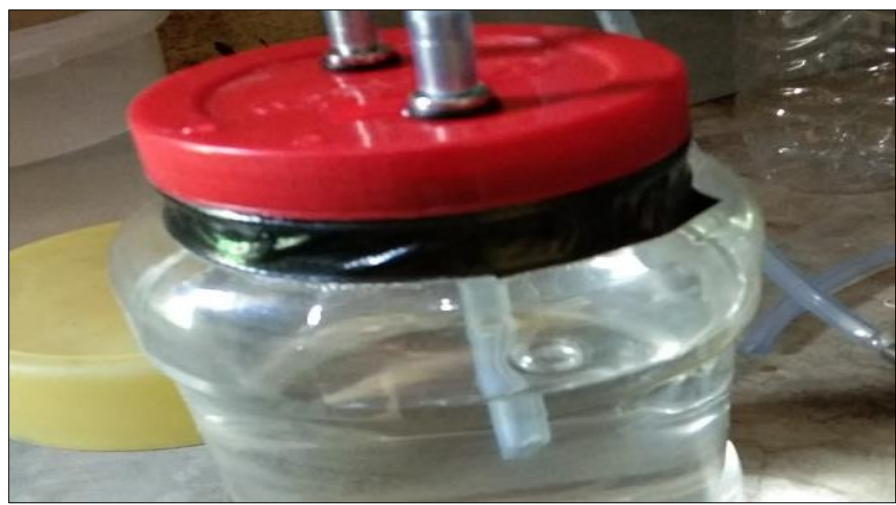

Gambar 6. Water Trap

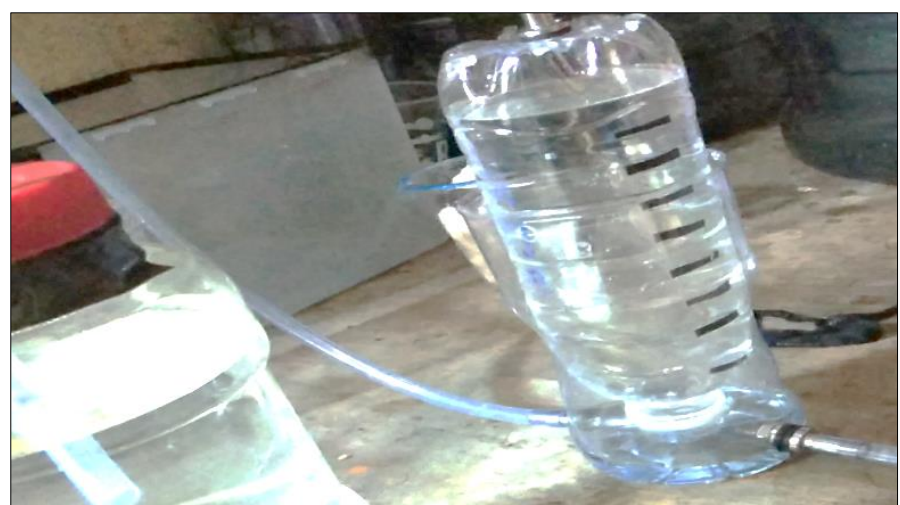

Gambar 7. Alat Ukur Volume Gas

\section{Prosedur Penelitian}

Prosedur dalam penelitian ini meliputi beberapa langkah-langkah, yaitu:

1. Perancangann generator $\mathrm{HHO}$, meliputi pembuatan plat elektroda besi, pengeboran dan pemasangan dop ban tubeless sebagai niple pada wadah atau toples vakum, serta termometer, dan pembuatan water trap.

2. Perancangan sistem kelistrikan generator $\mathrm{HHO}$, meliputi instalasi kabel-kabel sebagai sumber daya dari generator $\mathrm{HHO}$, menggunakan volt ampere meter sebagai display tegangan dan arus yang digunakan generator $\mathrm{HHO}$, saklar on/off untuk mengatur penghubungan arus.

3. Pengambilan data, meliputi mencatat waktu yang diperlukan untuk menghasilkan $50 \mathrm{ml}$ gas $\mathrm{HHO}$, mencatat tegangan dan arus yang diperlukan 
generator $\mathrm{HHO}$, mencatat $\mathrm{pH}$ air sebelum dan sesudan dielektrolisis, dan mencatat termperatur air pada termometer.

4. Pengolahan data, meliputi perhitungan laju aliran gas $\mathrm{HHO}$, perhitungan daya yang digunakan generator $\mathrm{HHO}$, perhitungan energi listrik yang digunakan generator $\mathrm{HHO}$, pergitungan efisiensi generator $\mathrm{HHO}$.

\section{Diagram Alir}

Digram alir pada penelitian ini dapat dilihat pada Gambar 8.

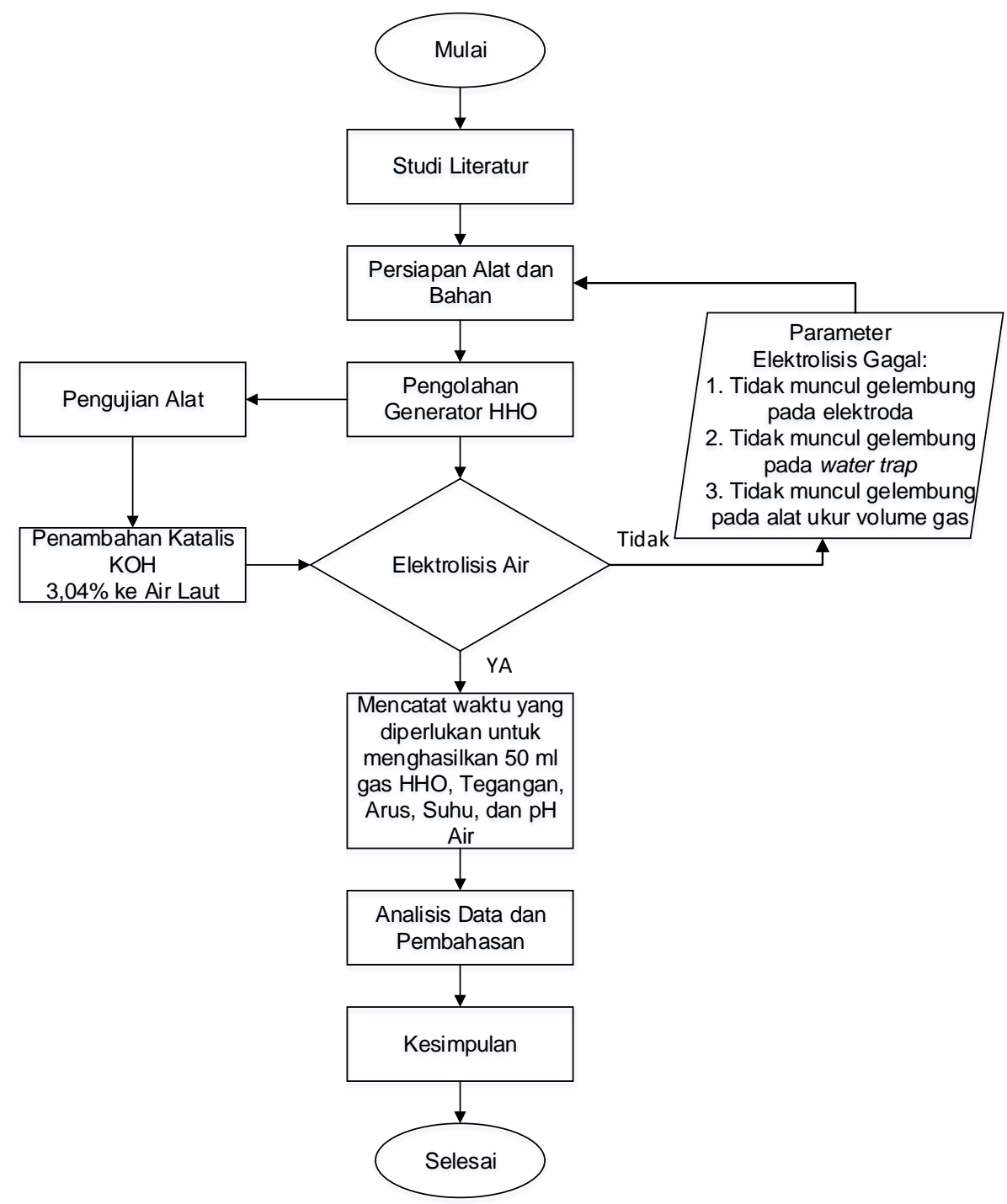

Gambar 8. Diagram Alir Penelitian

\section{HASIL DAN PEMBAHASAN}

Dalam pengujian yang dilakukkan di Workshop Teknik Mesin Universitas Lambung Mangkurat, diambil data berupa $\mathrm{pH}$ air laut sebelum ditambah katalis, $\mathrm{pH}$ air laut setelah ditambah katalis, dan $\mathrm{pH}$ air laut sesudah dielektrolisis menggunakan $\mathrm{pH}$ meter jenis pen. Tegangan dan arus menggunakan volt ampere meter digital. Waktu diperlukan generator untuk menghasilkan per $50 \mathrm{ml}$ menggunakan stopwatch. Temperatur air menggunakan termometer. 
Tabel 1. Data hasil pengujian elektrolisis

\begin{tabular}{|c|c|c|c|c|c|c|c|c|c|c|}
\hline \multirow{2}{*}{ No. } & \multirow{2}{*}{$\begin{array}{r}\text { Jarak } \\
(\mathrm{mm})\end{array}$} & \multirow{2}{*}{$\begin{array}{c}\mathrm{pH} \text { Air } \\
\text { Laut }\end{array}$} & \multicolumn{2}{|c|}{$\mathrm{pH}$} & \multirow{2}{*}{ Katalis } & \multirow{2}{*}{\begin{tabular}{|l} 
Volume \\
Gas (ml)
\end{tabular}} & \multirow{2}{*}{$\begin{array}{l}\text { Waktu } \\
\text { (sekon) }\end{array}$} & \multirow{2}{*}{$\begin{array}{c}\text { Tegangan } \\
\text { (Volt) }\end{array}$} & \multirow{2}{*}{$\begin{array}{c}\text { Arus } \\
\text { (Ampere) }\end{array}$} & \multirow{2}{*}{\begin{tabular}{|c} 
Temperatur \\
$\left({ }^{\circ} \mathrm{C}\right)$
\end{tabular}} \\
\hline & & & Sebelum & \begin{tabular}{|l|} 
Sesudah \\
\end{tabular} & & & & & & \\
\hline 1 & \multirow{6}{*}{2} & \multirow{18}{*}{7,8} & \multirow{18}{*}{12,8} & \multirow{6}{*}{12,9} & \multirow{18}{*}{$3,04 \%$} & 50 & 55,6 & 2,2 & 9,8 & \multirow{6}{*}{31} \\
\hline 2 & & & & & & 100 & 111 & 2,1 & 9,9 & \\
\hline 3 & & & & & & 150 & 168,3 & 2,3 & 9,6 & \\
\hline 4 & & & & & & 200 & 227 & 2,2 & 9,4 & \\
\hline 5 & & & & & & 250 & 283,9 & 2,1 & 9,7 & \\
\hline 6 & & & & & & 300 & 343 & 2,3 & 9,2 & \\
\hline 1 & \multirow{6}{*}{4} & & & \multirow{6}{*}{13} & & 50 & 61,8 & 2,2 & 11,2 & \multirow{6}{*}{32} \\
\hline 2 & & & & & & 100 & 123,6 & 2,3 & 11,1 & \\
\hline 3 & & & & & & 150 & 186 & 2,3 & 11,4 & \\
\hline 4 & & & & & & 200 & 250,2 & 2,2 & 11,3 & \\
\hline 5 & & & & & & 250 & 313,2 & 2,3 & 11,5 & \\
\hline 6 & & & & & & 300 & 376,8 & 2,3 & 11,3 & \\
\hline 1 & \multirow{6}{*}{6} & & & \multirow{6}{*}{13,1} & & 50 & 65,4 & 2,4 & 12,1 & \multirow{6}{*}{33} \\
\hline 2 & & & & & & 100 & 134,4 & 2,5 & 12,2 & \\
\hline 3 & & & & & & 150 & 200,4 & 2,4 & 11,5 & \\
\hline 4 & & & & & & 200 & 268,8 & 2,3 & 11,6 & \\
\hline 5 & & & & & & 250 & 335,4 & 2,5 & 12,4 & \\
\hline 6 & & & & & & 300 & 407,4 & 2,4 & 12,1 & \\
\hline
\end{tabular}

Dari data diatas kemudian dihitung sehingga didapatkan data laju aliran gas $\mathrm{HHO}$, daya listrik yang digunakan, energi listrik yang digunakan, dan efisiensi generator $\mathrm{HHO}$.

Tabel 2. Data hasil perhitungan laju aliran gas $\mathrm{HHO}$

\begin{tabular}{|c|c|c|c|c|}
\hline No. & Jarak (mm) & Volume Gas (ml) & Waktu (sekon) & $\mathrm{Q}_{\text {нно }}(\mathrm{ml} / \mathrm{s})$ \\
\hline 1 & \multirow{6}{*}{2} & 50 & 55,6 & 0,9 \\
\hline 2 & & 100 & 111 & 0,9 \\
\hline 3 & & 150 & 168,3 & 0,89 \\
\hline 4 & & 200 & 227 & 0,88 \\
\hline 5 & & 250 & 283,9 & 0,88 \\
\hline 6 & & 300 & 343 & 0,87 \\
\hline 1 & \multirow{6}{*}{4} & 50 & 61,8 & 0,81 \\
\hline 2 & & 100 & 123,6 & 0,81 \\
\hline 3 & & 150 & 186 & 0,81 \\
\hline 4 & & 200 & 250,2 & 0,8 \\
\hline 5 & & 250 & 313,2 & 0,8 \\
\hline 6 & & 300 & 376,8 & 0,8 \\
\hline 1 & \multirow{6}{*}{6} & 50 & 65,4 & 0,76 \\
\hline 2 & & 100 & 134,4 & 0,74 \\
\hline 3 & & 150 & 200,4 & 0,75 \\
\hline 4 & & 200 & 268,8 & 0,74 \\
\hline 5 & & 250 & 335,4 & 0,75 \\
\hline 6 & & 300 & 407,4 & 0,74 \\
\hline
\end{tabular}


Tabel 3. Data hasil perhitungan daya

\begin{tabular}{|c|c|c|c|c|}
\hline No. & Jarak (mm) & Tegangan (Volt) & Arus (Ampere) & Daya (Watt) \\
\hline 1 & \multirow{6}{*}{2} & 2,2 & 9,8 & 21,6 \\
\hline 2 & & 2,1 & 9,9 & 20,8 \\
\hline 3 & & 2,3 & 9,6 & 22,1 \\
\hline 4 & & 2,2 & 9,4 & 20,7 \\
\hline 5 & & 2,1 & 9,7 & 20,4 \\
\hline 6 & & 2,3 & 9,2 & 21,2 \\
\hline 1 & \multirow{6}{*}{4} & 2,2 & 11,2 & 24,6 \\
\hline 2 & & 2,3 & 11,1 & 25,5 \\
\hline 3 & & 2,3 & 11,4 & 26,2 \\
\hline 4 & & 2,2 & 11,3 & 24,9 \\
\hline 5 & & 2,3 & 11,5 & 26,5 \\
\hline 6 & & 2,3 & 11,3 & 26 \\
\hline 1 & \multirow{6}{*}{6} & 2,4 & 12,1 & 29 \\
\hline 2 & & 2,5 & 12,2 & 30,5 \\
\hline 3 & & 2,4 & 11,5 & 27,6 \\
\hline 4 & & 2,3 & 11,6 & 26,7 \\
\hline 5 & & 2,5 & 12,4 & 31 \\
\hline 6 & & 2,4 & 12,1 & 29 \\
\hline
\end{tabular}

Tabel 4. Data hasil perhitungan energi listrik

\begin{tabular}{|c|c|c|c|c|}
\hline No. & Jarak (mm) & Daya (Watt) & Waktu (sekon) & Energi Listrik (Joule) \\
\hline 1 & \multirow{6}{*}{2} & 21,6 & 55,6 & 1198,7 \\
\hline 2 & & 20,8 & 111 & 2307,7 \\
\hline 3 & & 22,1 & 168,3 & 3716,1 \\
\hline 4 & & 20,7 & 227 & 4694,4 \\
\hline 5 & & 20,4 & 283,9 & 5783 \\
\hline 6 & & 21,2 & 343 & 7257,9 \\
\hline 1 & \multirow{6}{*}{4} & 24,6 & 61,8 & 1522,8 \\
\hline 2 & & 25,5 & 123,6 & 3155,5 \\
\hline 3 & & 26,2 & 186 & 4876,9 \\
\hline 4 & & 24,9 & 250,2 & 6220 \\
\hline 5 & & 26,5 & 313,2 & 8284,1 \\
\hline 6 & & 26,0 & 376,8 & 9793 \\
\hline 1 & \multirow{3}{*}{6} & 29,0 & 65,4 & 1899,2 \\
\hline 2 & & 30,5 & 134,4 & 4099,2 \\
\hline 3 & & 27,6 & 200,4 & 5531 \\
\hline
\end{tabular}




\begin{tabular}{|l|l|l|l|l|}
\hline 4 & 26,7 & 268,8 & 7171,6 \\
\hline 5 & 31,0 & 335,4 & 10397,4 \\
\cline { 3 - 4 } & & 29,0 & 407,4 & 11830,9 \\
\cline { 3 - 4 } & & 29,4 & \\
\hline
\end{tabular}

Tabel 5. Data hasil perhitungan efisiensi generator $\mathrm{HHO}$

\begin{tabular}{|c|c|c|c|}
\hline No. & Jarak (mm) & Daya (Watt) & ๆ Generator $\mathrm{HHO}(\%)$ \\
\hline 1 & \multirow{6}{*}{2} & 21,6 & 23,31 \\
\hline 2 & & 20,8 & 24,17 \\
\hline 3 & & 22,1 & 22,76 \\
\hline 4 & & 20,7 & 24,3 \\
\hline 5 & & 20,4 & 24,67 \\
\hline 6 & & 21,2 & 23,75 \\
\hline 1 & \multirow{6}{*}{4} & 24,6 & 20,39 \\
\hline 2 & & 25,5 & 19,68 \\
\hline 3 & & 26,2 & 19,17 \\
\hline 4 & & 24,9 & 20,21 \\
\hline 5 & & 26,5 & 19 \\
\hline 6 & & 26,0 & 19,33 \\
\hline 1 & \multirow{6}{*}{6} & 29,0 & 17,3 \\
\hline 2 & & 30,5 & 16,48 \\
\hline 3 & & 27,6 & 18,21 \\
\hline 4 & & 26,7 & 18,83 \\
\hline 5 & & 31,0 & 16,21 \\
\hline 6 & & 29,0 & 17,3 \\
\hline
\end{tabular}

\section{Laju Aliran Gas HHO}

Gambar 9. Menunjukkan hubungan jarak dan volume gas $\mathrm{HHO}$ yang dihasilkan terhadap laju aliran gas $\mathrm{HHO}$ yang dilakukan pada proses elektrolisis. 


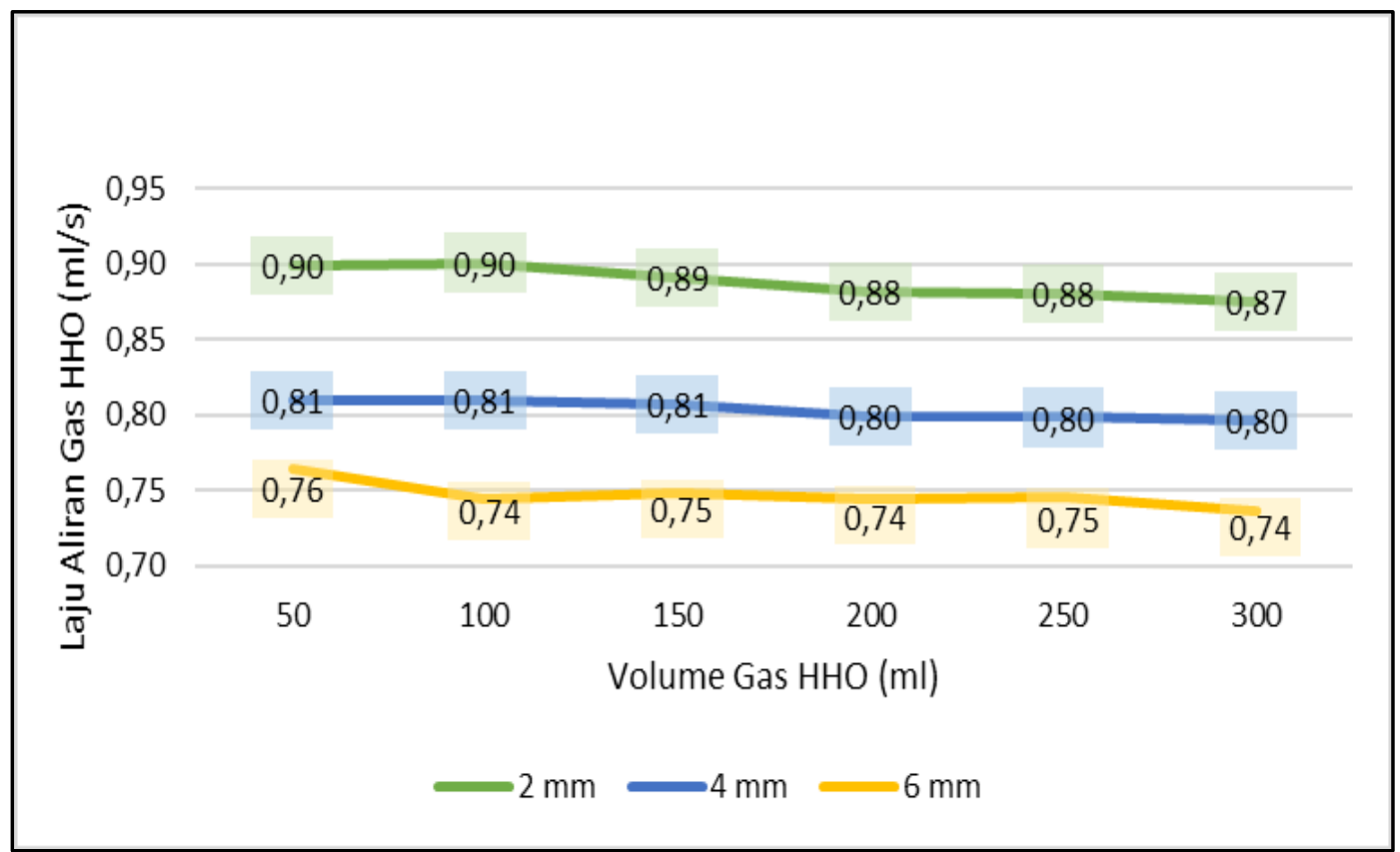

Gambar 9. Grafik Hubungan Laju Aliran Gas HHO terhadap Jarak Antar Plat dan Volume Gas HHO

Dari Gambar 9. dapat dilihat hubungan laju aliran gas $\mathrm{HHO}$ dengan volume gas $\mathrm{HHO}$ yang dihasilkan dari $50 \mathrm{ml}$ sampai dengan $300 \mathrm{ml}$ dengan variasi jarak antar elektroda menggunakan katalis $\mathrm{KOH}$ (Kalium Hidroksida) dengan jarak 2 $\mathrm{mm}, 4 \mathrm{~mm}$ dan $6 \mathrm{~mm}$ menunjukkan lajuran aliran gas yang didapatkan tidak terlalu jauh turun atau naik di masing-masing jarak antar elektroda, terlihat bahwa di jarak elektroda $2 \mathrm{~mm}$ laju aliran gas $\mathrm{HHO}$ yang paling tinggi didapatkan dengan rata-rata $0,89 \mathrm{ml} / \mathrm{s}$, diikuti jarak $4 \mathrm{~mm}$ dengan rata-rata $0,80 \mathrm{ml} / \mathrm{s}$ dan paling rendah pada jarak $6 \mathrm{~mm}$ dengan rata-rata $0,75 \mathrm{ml} / \mathrm{s}$. Hal ini dikarenakan pada jarak $2 \mathrm{~mm}$ gelembung-gelembung gas lebih banyak didapatkan dibandingkan pada jarak $4 \mathrm{~mm}$ dan $6 \mathrm{~mm}$.

Munculnya gelembung-gelembung juga sebagai parameter-parameter jika proses elektrolisis air berhasil. Gelembung-gelembung kecil dapat ditemukan pada plat elektroda dan akan terkumpul pada bagian atas generator, kemudian akan muncul gelembung besar pada water trap yang diteruskan ke alat ukur volume gas.

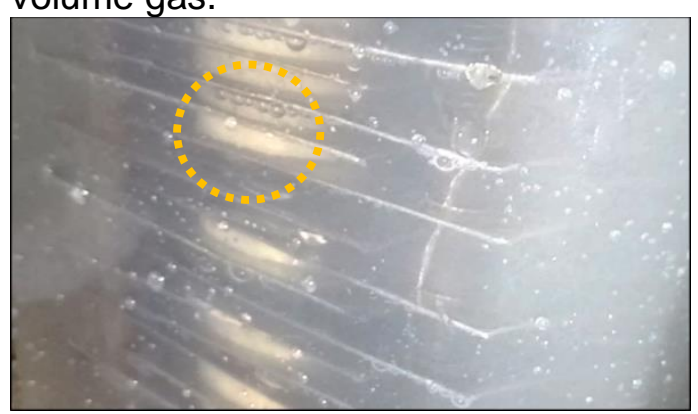

(a)

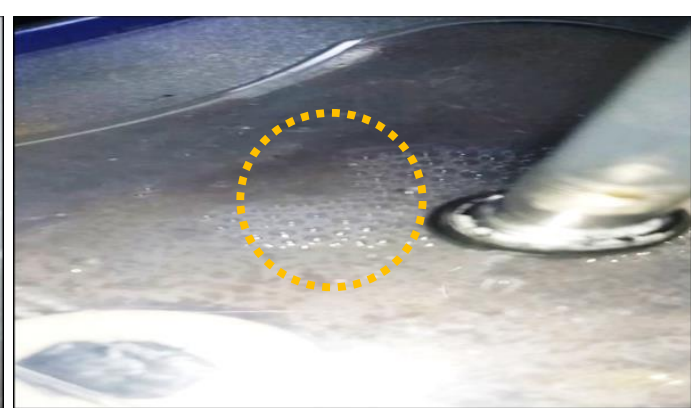

(b)

Gambar 10. Gelembung-Gelembung (a). Pada Plat Elektroda (b). Pada Bagian Atas Generator

\section{Efisiensi Generator HHO}

Gambar 11. Menunjukkan hubungan jarak dan volume gas $\mathrm{HHO}$ yang dihasilkan terhadap efisiensi generator $\mathrm{HHO}$ untuk menghasilkan gas $\mathrm{HHO}$. 


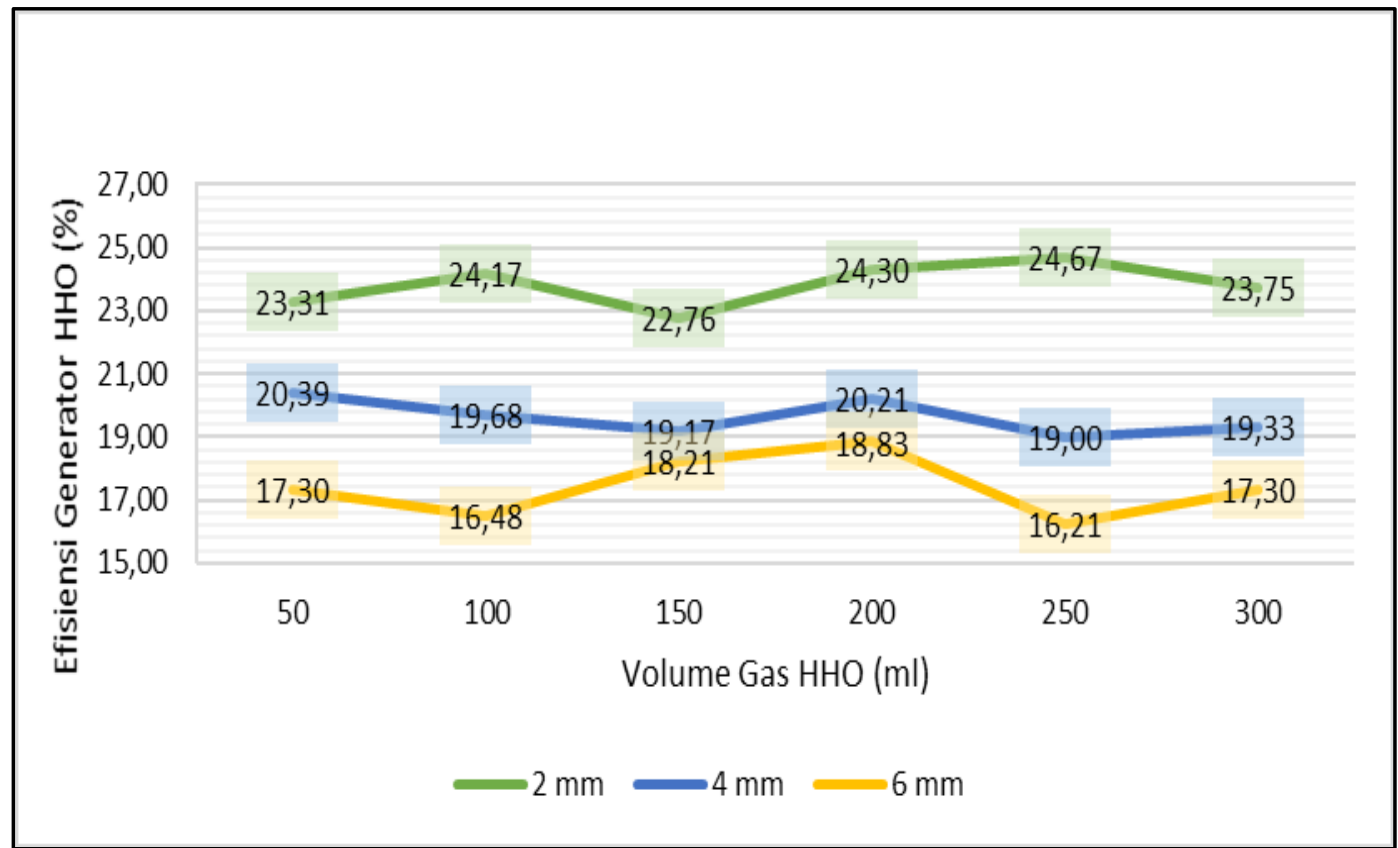

Gambar 11. Grafik Hubungan Efisiensi Generator HHO terhadap Jarak Antar Plat dan Volume Gas HHO

Dari Gambar 11. dapat dilihat efisiensi pada setiap volume gas berurutan yang dihasilkan dari $50 \mathrm{ml}$ hingga $300 \mathrm{ml}$ bahwa efisiensi generator $\mathrm{HHO}$ berubah-ubah pada setiap jarak dengan didapatknya efisiensi tertinggi pada jarak plat $2 \mathrm{~mm}$ dengan rata-rata efisiensi sebesar 23,83\%, diikuti jarak $4 \mathrm{~mm}$ dengan rata-rata efisiensi sebesar 19,63\% dan efisiensi terendah pada jarak 6 $\mathrm{mm}$ dengan rata-rata efisiensi sebesar $17,39 \%$. Hal ini dapat dipengaruh oleh beberapa faktor, yaitu volume gas $\mathrm{HHO}$ yang dihasilkan, massa jenis gas $\mathrm{HHO}$, LHV, dan daya yang digunakan untuk melakukan proses elektrolisis.

\section{KESIMPULAN}

Dari hasil yang didapatkan dapat disimpulkan bahwa untuk produktivitas generator $\mathrm{HHO}$ tercepat untuk menghasilkan gas $\mathrm{HHO}$ pada jarak $2 \mathrm{~mm}$ dengan rata-rata laju aliran $0,89 \mathrm{ml} / \mathrm{s}$, diikuti jarak $4 \mathrm{~mm}$ dengan rata-rata laju aliran 0,80 $\mathrm{ml} / \mathrm{s}$, dan jarak $6 \mathrm{~mm}$ dengan rata-rata laju aliran $0,75 \mathrm{ml} / \mathrm{s}$, sedangkan untuk efisiensi pada generator $\mathrm{HHO}$ tertinggi pada jarak $2 \mathrm{~mm}$ dengan rata-rata efisiensi $23,83 \%$, diikuti jarak $4 \mathrm{~mm}$ dengan rata-rata efisiensi $19,63 \%$, dan diikuti jarak $6 \mathrm{~mm}$ dengan rata-rata efisiensi $17,39 \%$.

\section{DAFTAR PUSTAKA}

Gohar, G. A. \& Hassan R. 2017. Comparative Analysis of Performance Chacateristicts of $\mathrm{Cl}$ Engine with and without HHO gas (Brown Gas). Adv Automob Eng 2017, 6:4. Pakistan: Institute of Information Technology, Sahiwal.

Isana, SYL. 2010. Perilaku Sel Elektrolisis Air dengan Elektroda Stainless Steel. Yogyakarta: Prosiding Seminar Nasional Kimia dan Pendidikan Kimia 2010. Lowrie, P.E.W. 2005. "Mitzubishi Cyclon". Procending of Elektrolytic Gas, USA.

Marayanti, M. 2008. Larutan Elektrolit dan Non Elektrolit. Jurusan Pendidikan Kimia FPMIPA. Universitas Pendidikan Indonesia.

Marlina, E. dkk. 2016. Pengaruh Variasi Larutan Elektrolit Terhadap Produksi Brown's Gas. Info Teknik, Vol. 17, No. 2, Desember 2016: 187-196. 
Nugraha, S. 2016. Outlook Energi Indonesia 2016. Jakarta: Dewan Energi Nasional.

Wahyudin, I., Harus L. G. 2012. Characteristics Study HHO gas Generator Wet Cell and its Application in 1300cc Engined Vehicle. Jurnal Teknik POMITS, Vol. 1, No. 1, Hal. 1-6.

Yanuar \& Djoko. 2013. Studi Karakteristik Generator Gas HHO Tipe Dry Cell dan Wet Cell berdimensi $80 \times 80 \mathrm{~mm}$ dengan Penambahan PWME-3 FF (1KHz). Surabaya: ITS. 